\title{
Hyper Reality in the Accountability of the Local Budgets Implementation: A Critical Interpretive Study
}

\author{
Ikhsan Budi Riharjo ${ }^{1}$, Made Sudarma ${ }^{2}$, Gugus Irianto $^{3} \&$ Rosidi $^{4}$ \\ ${ }^{1}$ Doctoral Program of Economics and Business Faculty, Brawijaya University Malang, Indonesia \\ ${ }^{2}$ Economics and Business Faculty, Brawijaya University Malang, Indonesia \\ Correspondence: Priyono, Post Graduate Program University Dr. Soetomo, Surabaya, Indonesia. E-mail: \\ priyono.unu_sidoarjo@yahoo.com
}

Received: August 7, 2015

Accepted: September 10, 2015

Online Published: September 18, 2015

doi:10.5539/ijbm.v10n10p240

URL: http://dx.doi.org/10.5539/ijbm.v10n10p240

\begin{abstract}
The purpose of this study was to interpret the comprehension of the local government element (executive and legislative), above the meaning of the sign/symbol of accounting (efficiency and effectiveness)as a measure of the success of the implementation of the budget. The study was designed with a qualitative approach and using critical interpretive paradigm. the research site is the local government of XX District, Central Java Province, Indonesia. The data collection has been carried out by conducting in-depth interview technique and documentation. Baudrillard critical theory is used as the analysis and discussion which is focused on hyper-reality and simulation concept.

The result of the research shows that, the successful of the budget implementation which is prepared in the Budget Implementation Accountability Report (LPP-APBD), is significant by the performance of efficiency and effectiveness. The reality performance takeoverthrough simulation model that has generated the hyper-reality sign, because of the efficiency and effectiveness signs cannot represent the actual reality. Even it deviates from the reality itself. Based on Baudrillard's sign relation, the relation between the efficiency performance sign and its referential reality is known as a sign-to-referent as image, because the sign does not fully represent the reality. Meanwhile the relation between the performance effectiveness with its referential reality is known as a sign-to-referent as model, since the sign of the performance effectiveness does not represent the objective reality at all. It is refers to the created simulation model only.
\end{abstract}

Keywords: accountability, the budget implementation, efficiency and effectiveness, sign, referential-reality, simulation, hyper-reality

\section{Introduction}

Organization is essentially a set of centers of responsibility, which is used as a basis for developing a control structure. Important aspects that need to be developed in a management control system according to Anthony and Govindarajan (2004, p. 147) is a measure of the performance of the managers responsible for the centers of responsibility, based on the criteria of efficiency and effectiveness relevant. The attention to the relevance in measuring performance attracted the attention of previous studies, which emphasizes the linkage between performance, strategic plans and objectives of the organization (Atkinson et al., 1997; Mwita, 2000; Robinson, 2003; Cavalluzzo \& Ittner, 2004; Denton, 2005; Halachmi, 2005).

At governmental organizations, control system developed based regulation. Performance information not only for consumption management, but also in the public space. Public involvement is what drives the paradigm shift in the management system of government, primarily related to the relationship between government and society. Paradigm change of government management systems as referred to is the use of the approach of New Public Management (NPM) in the management system of government. This approach focuses on the management of public sector performance-oriented, rather than on the policy (Christensen \& Laegreid, 2001; Hoque, 2005). Issues that arise in the implementation of NPM according Mwita (2000) is a management accounting role in meeting the information needs based on the principles of NPM. Hoque Z. and J. Moll (2001) explains that the role of accounting in the public sector reform plays an important role in improving accountability, efficiency and effectiveness of public sector services. Implementation of NPM in the government organizations is intended to 
address the challenges faced in meeting public expectations. Mwita (2000) states that the NPM philosophy is customer-based approach, which aims to improve the implementation of quality public services.

Financial statements and performance reports presented in the Accountability Report Implementation budget (APBDLPP) will be able to become an effective communication medium, if it is able to represent what is intended by the provider of information, and can convince the user that the meaning contained in it can be understood. Thus meaning to be communicated by the government in fact is the meaning contained in the financial statements and performance reports. Nugroho (2010) stated that the new meaning earnestly meaningful, if he is not only valuable for himself (the reporting entity), but simultaneously also can be communicated to others (stakeholders).

Accountability of the budget as described above, is expected to promote the establishment of accountability, as well as repair of local government performance in implementing its programs and activities. Study Cavalluzzo and Ittner (2004) on the factors that affect the implementation, use and profit-oriented performance measurement system on the results in the United States, found that the implementation of the Government Performance and Results Act (GPRA) has successfully developed a comprehensive performance measurement to meet the provisions of the Act, but does not use the information further. Even Robinson (2003) indicated that the government performance measurement has been just promoted to make each unit of government appear to be more efficient and effective. Symbol of efficiency and effectiveness in government performance reports, is used as a sign to demonstrate the successful implementation of the budget, which is generated through the simulation process and tends to be directed to show the government's performance looks more efficiently and effectively.

Financial Statements and Reports notch performance as media accountability of the budget, serves as a language of communication for the government to stakeholders. Suwardjono (2005, p. 28) states that language is an important part of communication, message or meaning in the mind of the sender, symbolized in the form of expression of appropriate language so that the meaning is interpreted exactly as it was intended. For Gadamer (see Kaelan, 2002, p. 212) language (words) are not mere signs and symbolic forms of human creation, because the word is essentially belongs to reality, and the human role is really just searching for the right word, that word is the expression of reality. The attention to correspondence between symbol and reality symbolized, ensuring their shared interpretation between the parties convey a message to the party receiving the message

Accounting notch as the language proposed by Ijiri (1975), that accounting has many similarities with other languages, diverse business activities in a company are reported in the accounting statements by using accounting language. Furthermore it is said that, in addition to accounting related to measurement problems, also closely related to communication problems. (Belkaoui, 1980). In line with Belkaoui, Harb (2003, p. 23) states that the reason the language, grammar, or rhetoric, always subject to the rules of language and context, which sees language as a structure and a system or as conventions and symbolization-symbolization, namely as signs which shows the objects and symbols that indicate something.

The study on the relation between accounting mark with an object by using social theory based on the philosophy of critical theory Baudrillard, have been conducted by previous researchers (eg, Macintosh et al., 2000; Mattessih, 2003; Riduwan et al., 2010; Riduwan, 2012). Philosophically operational goals of business and government entities are basically no different, both aimed at the provision of goods and / or services.

Results of research Macintosh et al. (2000) regarding accounting mark, found that the sign (symbol) accounting no longer refers to the objective reality but instead circled in the world of hyper reality of the models themselves. In line with the Macintosh et al., Study Riduwan (2012) on the meaning of accounting earnings show that, within the framework of the interpretation of the non-accountant business practitioners, describes the accounting profit world hyper reality. Accounting profit symbol separated from the actual reality they are expected to be represented.

Unlike the Macintosh et al. and Riduwan, Mattessih (2003) revealed that all accounting symbols always have a relationship with reality as a reference, however, the referential reality of accounting symbol is likely to be on a different level. This is consistent with the reasons given Riduwan (2012) in explaining the differences in interpretation of accounting profit according to the non-accountant business practitioners with the meaning of the accounting profit according to accountants. Differences in interpretation of the meaning of such profits occur because accountants and non-accountants living in a different habitus.

Communication of accounting information will be effective if there are similarities between the provider and the user interpretation of information. Riduwan et al. (2010) explains that the differences in interpretation of accounting profit will affect the effectiveness of communication of information, because the true reality want to be interpreted by the symbol turns profit interpreted differently by the parties involved in the communication.

Based on the above, the purpose of this research is intended to interpret the understanding of the elements of the 
regional administration (executive and legislative), on the meaning of the sign / symbol of accounting (efficiency and effectiveness) as a measure of the success of the implementation of the budget, which is reflected in the budget LPP.

\section{Research Methods}

\subsection{As Interpretive Approach}

This study was designed using qualitative research. Qualitative research is research that aims to understand the phenomenon of what is experienced by research subjects, on the condition of natural objects (natural setting), as well as the results of research more emphasis on the significance of the generalization. Social reality or the object of research in qualitative research, is seen as something that is holistic, complex, dynamic and full of meaning (Sugiyono, 2012, p. 1). The paradigm used in this study is a critical interpretive paradigm.

Discussion informant interpretation of the meaning of the efficiency and effectiveness of the implementation of the budget which is reflected in the Budget Implementation Accountability Report (LPPAPBD), carried out using Baudrillard critical theory centered on the concept of simulation and hyper reality as knives analysis. The concept of simulation is used to analyze how the models produced performance efficiency and effectiveness through the simulation process. While the concept of hyper reality which is generated through the simulation process, is used to analyze the reality of the performance as a referential object symbolized through simulation mechanism.

\subsection{Data Collection Techniques and Informant Research}

Techniques of data collection is done through in-depth interview technique (depth interview) with the informant, and carried out unstructured and informal in various situations. In testing the credibility of the data obtained during the study, researchers used the method of triangulation of sources and techniques. Triangulation source, done by getting data from different sources through interview techniques. In addition to using triangulation sources, researchers are also using triangulation techniques, of in-depth interview techniques and engineering documentation (see Sugiyono, 2012, pp. 83-85).

The main information in this research was obtained from interviews, and performed with unstructured. Election informant by purposive, based on the consideration that the informant chosen is related to the accountability of the local government budget in District XX (not her real name), Central Java, Indonesia.

Informants were selected in this study include: first, the element of the Executive, which consists of: (a) Regional Financial Management Officer (PPKD) in the Regional Finance Management Task Unit ( SKPKD), (b) Regional Development Planning Board (Bappeda), (c) Work Unit (SKPD) as the users and implementers of the budget . Both are elements of the Legislative, the Chairman and members of parliament, as one of the elements of the regional administration which have a legislative function, budgeting and supervision.

\subsection{Unit Study}

Based on the purpose or focus of research, study unit (unit of analysis) in this study is an organization that is directly related to the accountability of the budget, as well as individuals who are in it. Organization in question is the Elements Organizer Local Government, namely the executive and legislative branches.

\section{Results and Discussion}

\subsection{Accountability Report (LPPAPBD): Basic Performance Assessment Efficiency and Effectiveness of Budget}

LPP budget that contains information that is comprised of Financial Statements and Performance Report, is a medium that explain the performance of the implementation of policies, programs and activities of the government. Symbols or signs of accounting has been used to reflect the performance of implementation of the budget is the achievement of performance efficiency and effectiveness, which indicates that the local government has succeeded /failed in implementing policies, programs and activities. Role of Financial Statements to evaluate the performance of the implementation of the budget based on performance efficiency and effectiveness is confirmed in Government Accounting Standards (Regulation No. 71, 2010):

"The financial statements are primarily used to determine the economic value of the resources used to carry out the operations of government, assess the financial condition, evaluate the effectiveness and efficiency of a reporting entity, and help determine the compliance of the laws and regulations" (Government Accounting Conceptual Framework, p. 24).

Government Accounting Standard (PSAP) No. 02 also confirms the usefulness of the Budget Realization Report (LRA), as one component of Local Government Finance Report (LKPD), is to evaluate the performance of the efficiency and effectiveness of the use of the budget: 
"LRA provides information regarding the realization of the overall budget that is useful in evaluating the performance of the government in terms of efficiency and effectiveness of the use of the budget" (PSAP, 2002, p. $5)$.

The basis for evaluating performance, efficiency and performance effectiveness of the implementation of programs and activities, is technically based on the performance reports conveyed by the reporting entity. In the context of accountability of local budgets, which meant reporting entity is the Local Government. Local Government obligation to submit a performance report also confirmed in the Government Regulation No. 8 of 2006 on Financial Reporting and Performance of Government Agencies:

"In the framework of accountability of the budget, each reporting entity shall prepare and present: (1) Financial Statements; and (2) Performance Report" (Article 2).

"Performance Report contains a summary of the output of each of the activities and outcomes of each program as set out in documents the implementation of the budget" (Article 17).

Based on the above regulations, the performance efficiency is achieved if the implementation of activities managed to achieve a certain output with low input, or the lowest input with maximum output. While the achievement of performance effectiveness means the ability to achieve results consistent with the objectives of the program.

Given the budget LPP goal is to provide an overview of financial efficiency and effectiveness of the implementation of policies, programs and activities, the necessary awareness of users report, particularly the legistative (DPRD) to understand the meaning of the information contained in the budget LPP. The position of Parliament in the system of accountability of the local budget is as key stakeholders involved directly together local government, ranging from discussion to supervise the follow-up results of the discussion of the budget LPP. Awareness to understand and interpret the meaning of the efficiency and effectiveness of which is described in the Financial Statements and Reports Performance, of course, must be connected with the principal task of the government to provide public goods or public service.

\subsection{Performance Reality Efficiency and Effectiveness of Budget Execution: In the Frame interpretation Executive}

Reality performance reported by local governments through financial statements and performance reports, intended to meet the demands for government accountability. As an implementation instrument of accountability, based on information contained in the financial statements, the public can find out where and how big source of income is derived and used, who obtain benefits over the usage of resources, as well as how the government uses and closing surplus/deficit. Whereas through government performance report, obtained information that describes the comparison between the performance targets with the realization of programs and activities. Under the regulation, the actual realization of the performance of activities measured by the output activity, while the actual realization of the program's performance is measured by the impact (impact) on the implementation of the policy.

Performance efficiency of the implementation of the budget, as long as it is understood by the executive as efficient use of the budget which is characterized by lower expenditure compared with the budget. While the effectiveness of the performance was marked by the achievement of performance targets or plans as outlined in the report on the performance of each unit in the structure of local government. For the working units (SKPD) that duties and functions of collecting revenues, performance effectiveness is also seen from the achievements realized income greater than the revenue budget set out in the budget. Some executives statement that confirms the basis used to assess achievement of performance efficiency and effectiveness of the implementation of the budget include:

"The efficiency and effectiveness in the implementation of the intensification and extension programs are measured at a small cost to produce big results. It can be seen from the Budget Realization Report. In addition there are other parameters that are used to assess the success of the Department of Revenue (DPPKAD) in achieving the program's performance and activities reported in the performance report"'Anw (Head SKPD-DPPKAD)].

"If we at SKPD, but they should maintain financial efficiency. We guard so that expenditures do not exceed the budget, and the achievement of performance according to plan.............so we caution when determining the budget so as not to inconvenience when making accountability report" [Al (SKPD)].

"As the executive budget, which is important to note, yes lest the implementation of programs and activities that go beyond the budget, so that efficient" [Bam (SKPD).

"Actually .........efficiency that arise when there is the remaining budget (SILPA). SILPA it arises because there expenditure savings, thus meaning there are efficiencies that can be achieved. But yes....fixed should notice results 
in accordance with the plan of action"[Rud (Head Bapeda)].

On another occasion, linked to the performance efficiency and effectiveness of the implementation of programs and activities, the Head for Development Planning Agency (Bapeda) District XX also revealed:

"The measures the performance of the existing government in the planning documents. Under the legistative, a measure of performance efficiency and effectiveness of the implementation of programs and activities is to use ratio".

From some explanations local government officials (executive) above, it appears there similarity perception in describing the reality of performance, efficiency and effectiveness of the implementation of the budget. Performance efficiency is defined as the actual use of the budget that does not exceed the defined budget (see tables 1 and 2), while the effectiveness of the performance seen from the achievement of planned activities as outlined in the report of the government's performance.

Performance revenue on education effectiveness is also demonstrated through the achievement of revenue targets were reported on realization of the budget (see table 2). The achievement of revenue targets as a measure of the success of the implementation of the budget, also described by local governments in the LPP budget:

In general, the realization of revenue (PAD) exceed the target of $114.08 \%$ of the target set by.....(LPP district budget XX: 15)

The achievement of revenue targets as a measure of the success of the implementation of the budget becomes meaningless, if the program is not in line with the increase in PAD target setting that is not based on the real potential of which is owned by the local government.

Related to the assessment of efficiency in the use of the budget, the ratio between actual and budget specified in the budget (Table 3), showed that in all components of expenditure, both operating expenditure and capital expenditure, the ratio is in the range of $85.68 \%$ to $99.31 \%$. In the group of operating expenditure, the ratio between actual and budget amounted to $95.07 \%$, while the group's capital expenditure amounted to $93.65 \%$, and overall amounted to $94.37 \%$. Claim XX district government in achieving performance efficiency so fantastic budget, which is based only on lower expenditures in comparison with the budget, ignoring the possibility of a larger budget allocation than actual needs, when the process of preparation and adoption of the budget is done jointly between the executive and legislative.

Table 1. Budget and actual revenue and expenditure

\begin{tabular}{llll}
\hline & BUDGET (Rp) & Realization (Rp) & Ratio (\%) \\
\hline Budget & 1.270 .579 .706 .000 & 1.304 .004 .470 .978 & 102,63 \\
Expenditure & 1.374 .447 .579 .000 & 1.297 .076 .712 .359 & 94,37 \\
Surplus /(Deficit) & $\mathbf{( 1 0 3 . 8 6 7 . 8 7 3 . 0 0 0 )}$ & $\mathbf{6 . 9 2 7 . 7 5 8 . 6 1 9}$ & \\
Financing & & & \\
Acceptance & 114.012 .437 .000 & 107.869 .939 .431 & 94,60 \\
Financing & 10.144 .564 .000 & 8.653 .243 .951 & 85,30 \\
Financing expenses & 103.867 .873 .000 & 99.216 .695 .480 & 95,51 \\
Net Financing & -- & $\mathbf{1 0 6 . 1 4 4 . 4 5 4 . 0 9 9}$ & \\
SILPA & & & \\
\hline
\end{tabular}

Source: LPPAPBD XX District for Fiscal Year 2012, p. 37.

Table 2. Details the budget and realization of local revenue

\begin{tabular}{llll}
\hline Locally-Generated Revenue & Budget (Rp) & Realization (Rp) & Ratio (\%) \\
\hline 1) Local Tax & 23.359 .752 .000 & 23.454 .798 .831 & 121,73 \\
2) Retribution & 13.103 .354 .000 & 13.600 .889 .981 & 103,80 \\
3)Results area separated Wealth Management & 5.479 .917 .000 & 4.640 .566 .066 & 80,71 \\
4) Other PAD legitimate & 70.937 .378 .000 & 82.400 .315 .211 & 116,16 \\
Number & $\mathbf{1 1 3 . 1 5 0 . 5 8 1 . 0 0 0}$ & $\mathbf{1 2 9 . 0 7 6 . 5 7 0 . 0 8 9}$ & $\mathbf{1 1 4 , 0 8}$ \\
\hline
\end{tabular}

Source :LPPAPBD XX District for Fiscal Year 2012, p. 38. 
In terms of performance effectiveness of the implementation of the budget, the local government district XX realization basing on the results / output, compared with the planned results / output of each program and activities presented in the performance report on each SKPD . SKPD performance reports inform budget and expenditure, as well as planned and actual results / outputs for each program and activity.

Table 3. Budget and actual expenditure (based shopping group)

\begin{tabular}{|c|c|c|c|}
\hline Operating Expenditure & Budget (Rp) & Realization (Rp) & Ratio (\%) \\
\hline 1) Shopping Employee & 670.676 .017 .000 & 645.688 .161 .449 & 96,27 \\
\hline 2) Goods and services spending & 254.906980 .000 & 235.320 .051 .087 & 92,31 \\
\hline 3) Subsidy & 2.484 .085 .000 & 2.483 .701 .500 & 99,31 \\
\hline 4) Shopping Grants & 62.882 .819 .000 & 57.879 .453 .462 & 92,04 \\
\hline 5) Social Assistance & 18.574 .250 .000 & 18.411 .600 .434 & 99,12 \\
\hline Number & 1.009.524.151.000 & 959.782 .967 .932 & 95,07 \\
\hline \multicolumn{4}{|l|}{ Capital Expenditue : } \\
\hline 1) Ground & 4.459 .578 .000 & 4.091 .625 .250 & 91,75 \\
\hline 2) Equipment and Machinery & 52.940 .412 .000 & 49.572 .440 .912 & 93,64 \\
\hline 3) Building and construction & 120.068 .261 .000 & 115.039 .561 .282 & 95,81 \\
\hline 4) Roads, Irrigation and Networks & 132.696.277.000 & 122.268 .714 .551 & 92,14 \\
\hline 5) Other Fixed Assets & 6.636 .090 .000 & 5.685 .529 .500 & 85,68 \\
\hline 6) Other assets & 546.661 .000 & 539.411 .000 & 98,67 \\
\hline Number & 317.347 .279 .000 & 297.197.282.495 & 93,65 \\
\hline
\end{tabular}

Source :LPPAPBD XX District for Fiscal Year 2012, p. 58 and 85.

Based on performance reports each SKPD presented in the Performance Report - LPP budget for Fiscal Year 2012 showed that, of all the programs and activities of the main tasks and functions on education, the realization of shopping not to exceed the budget set in the budget. While the various indicators used in assessing the successful implementation of programs and activities at all SKPD, showing results so fantastic. Where the realization of the results of the implementation of programs and activities, $100 \%$ according to plan. No single outcome measure used to assess the success of the implementation of programs and activities deviate (exceeding or less) of the plan set.

$\mathrm{XX}$ affirmation district government in achieving performance efficiency and effectiveness of the implementation of the budget, also described in the concluding chapter in the budget LPP as follows:

"The successful achievement of targets and objectives that have been planned in the budget for Fiscal Year 2012, can not be separated from the hard work and togetherness that exists between the legislative and the executive as a partner alignment, and supported by the active participation of all citizens as well as the consolidation of security and stability in District XX" (LPP budget for Fiscal Year 2012, p. 239)

Affirmation of the role of local government structure (executive) and Parliament (legislative) to target and budget targets, is expected to politically legitimize the successful implementation of the budget. Moreover, also supported by the results of the Financial Statements District XX is used as a medium of accountability of the budget, which since 2010 has gained the highest appreciation in the form of an unqualified opinion from the Audit Board of the Republic of Indonesia (BPKRI) as an independent auditor.

\subsection{Performance Reality Efficiency and Effectiveness of Budget Execution: In the Frame interpretation Parliament (Legislative)}

As one element of the local government, the role of Parliament who are directly involved in the system of accountability of the budget, is very concerned to understand the meaning of the efficiency and effectiveness of the implementation of the budget. It is intended that the legislature can ensure that the programs and activities of local government has been run as it should, especially in the provision of public goods in line with expectations, as well as welfare and justice-oriented community based on the vision and mission of the local government. Not much different from the executive, some of their views (DPRD) on the meaning of efficiency and effectiveness are as follows:

"The success in implementing the government's budget yes......principally act in accordance with the planning 
documents, meaning it is efficient and effective" [Lk (DPRD)].

"The implementation of the budget it should be efficient and effective....the efficient saving, saving of the budget that has been set and the saving in terms of time. Being effectively targeted yes ....we can see from the report on education" [Mas (DPRD)].

"To evaluate the implementation of the budget, we usually see in the Budget Realization Report, we look at the percentage of absorption, it runs activities that its uptake optimal" [Mas (DPRD)].

"Our job as legislators is to carry out oversight function, particularly maintaining the SKPD that efficient use of the budget, namely ensuring SKPD not use a bigger budget than we have agreed to in the budget" [Sut (DPRD)].

Awareness of Parliament to watch the interests of the public in assessing the successful implementation of programs and activities, is also revealed by the statement of some legislators. Assessment of the performance, efficiency and effectiveness of budget implementation, need to pay attention to the impact of the implementation of programs and activities for the community, by evaluating the results of the activities that can be perceived benefits.

"The implementation of the budget it must be efficient and effective, which will benefit the public interest. For the community, the government program was successful when cheap food and clothing, school fees affordable, or free, there is a hole course, health is also served well. Anyway all services served well, it has managed to" [Zae (DPRD)].

"Achieving the efficiency and effectiveness of the implementation is easy anyway, now we determine the level of efficiency and effectiveness with specific ratios, tomorrow when the implementation is achieved anyway ......... the problem is how the contribution to the improvement of public welfare, as well as the vision and mission of the regents are: fair in prosperity, and prosperity in justice" [Suk (DPRD)].

Assertions to account budget implementation that can be understood by the public, as a medium that can realize the public accountability, presented by one of the local parliament commission chairman at XX (Kris):

"In preparing accountability reports on budget implementation, we hope the government adhered to the existing reality, which can be important in explaining to the public".

Achievement of performance efficiency and effectiveness of the implementation of the budget is so fantastic, as described in the LPP budget for Fiscal Year 2012, which ultimately approved by Parliament as an institution, indicating that the institution is a representation of society XX District, acknowledges that local governments have been successful in implementing the program and activities that have been set in the budget. However, recognition of performance efficiency and effectiveness of budget implementation which has not actually reflect reality, is also recognized by most actors in the power structure (DPRD). Linked to the achievement of performance implementation of the budget, Zam (DPRD) revealed:

"Honestly, the evaluation of the implementation of the budget in terms of efficiency and effectiveness based on the budget is still questionable why, for example in the implementation of human resource development activities budget, whether it is an effective measure can be seen from the number of training activities? It does not, it should be seen from its output, like what? the so. When programs and activities are planned in the Work Plan budget, the right should have been accompanied by the results to be achieved it like? It is often overlooked".

Is (DPRD) added, a target which is used as a measure of the success of the implementation of activities should also be considered:

"Friends of Parliament is actually necessary to master guidelines used, compared with the target, measures are used, it is important in order to evaluate the implementation of the budget".

Of the various arguments set forth above, according to a report presented in the realization of performance accountability of the budget (APBDLPP) none of them were qustion achievement of the performance (results / output) implementation of programs and activities that are identical to the plan set out in the budget.

Performance report presented in LPP budget and established through the Regional Regulation About Accountability Implementation of the budget, which shows the actual results / outputs that are $100 \%$ the same as the predetermined plan, as if it insists that the successful implementation of the budget information presented in the report, is true -Right reflect the actual reality. While on the other hand, with human limitations, it may be able to plan the future with certainty. Therefore, as God creature get the gift of reason and mind, as well as limitations, should be aware that it may be able to ensure the future, while the future we will face filled with uncertainty. 


\subsection{Referential Reality Efficiency and Effectiveness Performance Budget Implementation}

In the implementation of the budget accounting system, the efficiency and effectiveness of an accounting symbol, which is used to indicate the success of the government in the implementation of policies, programs and activities. As a symbol of accounting, information on the performance, efficiency and effectiveness of the implementation of the budget, will be communicated by the local government to stakeholders as media accountability. Therefore, the meaning of performance, efficiency and effectiveness should be linked to the reality of the implementation of programs and activities that will be represented. Thus the performance efficiency and effectiveness of the implementation of the budget, which is reflected in the Financial Statements and Reports Performance Realization (LPPAPBD) actually describes the realities that exist in the accounting entity (SKPD) and the reporting entity (local government).

With the use of the product of accounting (Financial Statements and Performance Report) as media accountability of the budget, in addition to the issue of measurement, the important thing that should be of concern is the problems associated with communication problems. The reality described in the accounting information through the accounting symbols, their meanings should be understood by the user, because in fact the symbol / mark accounting pour in accounting reports are the property of reality.

The interpretation of the performance efficiency and effectiveness of performance that indicates the success / failure of the government in implementing the budget, should Recognising the reality that agreed between the provider (local government) and the user (DPRD) information, because reality is used as a reference symbol of performance efficiency and effectiveness of budget implementation, which will be communicated by the providers and users of information within the accountability of the budget. The effectiveness of communication will happen, if both have a symmetric interpretation of reality performance is communicated via symbols efficiency and effectiveness of budget implementation.

An understanding of the meaning of the symbol / mark of accounting that reflects the successful implementation of the budget in a semiotic system, is inseparable from the rules set out in the regulation. Attention to the rule in understanding the meaning of performance efficiency and effectiveness of the implementation of the budget, is expected to be understood by providers and users collectively accounting mark. Belkaoui (1980) explains that as the language of communication, language symbols in accounting is the object of the language that is used to identify a specific meaning through syntactic arrangement or rules of grammar, a set of commonly used procedure called accounting techniques. Similar views were also expressed by Harb (2003: 23) who argued that the reason the language, grammar, or rhetoric, always subject to the rules of language and context, which sees language as a structure and a system or as conventions and symbolization-symbolization, as a sign -sign which shows the objects and symbols that indicate something. Use of the symbol / mark of accounting based rules, requires awareness of the providers and users of accounting reports to understand the signs of accounting in accordance with the referential reality, the reality marking the successful implementation of the budget based on performance efficiency and performance effectiveness.

In general, there are similarities in interpretation of the performance of financial efficiency and effectiveness of the achievement of performance objectives of the program and activities, among working unit implementing the existing budget in the structure of local government (the executive). Achievement of performance efficiency is defined as expenditures are lower than the budget set out in the budget. While the effectiveness of the implementation of the budget (performance effectiveness) is defined as the realization of the results of activities in accordance with the plan results in each program and activities set out in the Work Plan Budget (RKA) SKPD.

Executive interpretation of the performance efficiency and effectiveness of the implementation of the budget against the background by their desire to gain legitimacy, that they have been carrying out the mandate properly, in accordance with the duties and functions. The implications of a strong desire to show the performance of the implementation of the budget in accordance with the will of rulers, causing their reluctance to set targets according to their potential. Nur (DPRD) explains that:

"In connection with the target, when we often ask the commission meeting, but he said agencies (SKPD), if we set the target of the real right or targets too high, fear tomorrow is not reached, it is not desirable employer".

Kris (DPRD) one of the chairman of the commission in District XX Parliament also expressed:

"SKPD that typically raise objections if the target is in the (high), the target that they use an easy target for them to accomplish. In the case measures used should the rational measure, in accordance with the conditions of the District XX".

Imagine the performance, efficiency and effectiveness of budget execution performance, as at present on LKPD 
and Performance Report (LPPAPBD) as the reality of the successful implementation of the budget, of course, can not ignore the basis used in setting performance targets in planning and budget documents.

Although Parliament is directly involved in the discussion of targets and resource allocation inherent in every program and activity, most members of Parliament have the same interpretation by the executive on the meaning of performance, efficiency and effectiveness as a measure of the success of the implementation of the budget. Some others attributed the successful implementation of the budget with the interests of the community, which felt the direct impact of the implementation of the budget, particularly in terms of assessment of the effectiveness of the implementation of programs and activities. Assessment of the impact felt by the public, would require indicators of success associated with the interests of the community to get the public goods or services better. Unfortunately the performance measurement models presented in the Financial Statements and Performance Report, showed no impact indicators (outcomes) of each execution of programs and activities.

Performance reports contained in the LPP XX district budget provides information about: the budget and expenditure, as well as planned and actual results / outputs for each program and activity. Based on Performance Realization Report, the achievement of performance efficiency seen from the use of resources associated with the results of the activities. While the effectiveness of the performance assessment, based only on the suitability of the realization of the plan of the results that have been defined previously. Desire of some members of Parliament are linking the effectiveness of the implementation of the budget to the public interests, is meant to ensure that the outcome of each activity reported in the performance report, in accordance with the goals and objectives of the program are set out in planning documents.

\subsection{Hyper Reality in Accountability Budget Implementation}

In Big Indonesian Dictionary, said hyper defined as "above", "beyond", "excessive" or "out of bounds". Based on the meaning of the word hyper, heper reality can be interpreted as a reality or reality exceed limit excessive, that is the reality that transcend the concept, boundary definition and boundary principle.

Hyper reality is a concept that is generated through a mechanism called the simulation, Baudrillard reveal all that is real Becomes simulation (see Hidayat, 2012, p. 71), the expression above is a picture of the reality of the people who saw the object from space is cramped, as if reality actually. Reality not only be represented through the media, but can be engineered and simulated. Piliang (2012, p. 51) describes the simulation as a process of creating a reality that no longer refers to the reality in the real world as a reference, and now he was transformed into a kind of second reality which reference is himself (simulacrum of a simulacrum).

The simulation process in preparing performance reports presented in the budget LPP, visible when the local government units serving the gains of the effectiveness of the implementation of the program, based on the realization of output compared to the output plan specified in the work plan budget. The realization of program outputs and activities in all work units are entirely in accordance with the established plan, if desired performance describe reality, although in simulating the performance of the effectiveness of the implementation of the budget, ignoring the result of the output of the program and budget are perceived by the public as a target program, which it should be represented in the report on the performance of each unit of local government.

Achievement of performance efficiency (technical and economical) have also been ignoring the sociological aspect, in the absence of alternative programs offered to the people who receive and feel as a result of the implementation of the program and budget. Performance efficiency described in the Performance Report presented in LPP budget, not associated with the selection of appropriate activities as the basis for allocating resources, linked to the objectives of the program and budget. Efficiency performance assessment based solely on the fact that expenditures do not exceed the budget, as well as the realization of outputs in accordance with the plan set out in the budget.

Symbol signified the successful implementation of the budget through the performance efficiency and effectiveness, as if a picture of reality, when in fact it is just a simulation of reality presented in the performance report, signs indicating reality even deviate from reality represented. Plato looked simulacrum as a negative trend (see Piliang, 2010, p. 9), because through simulacrum someone is only able to copy or imitate the external appearance with not perfect, but was unable to duplicate the idea or form behind sightings.

Referring to the concept of tagging Saussure, Baudrillard in Hidayat (2012, p. 67) states based on the perspective of semiology, he saw a sign consisting of bookmarks (signifier) and signified (signified). Marker refers to a marker, then refer to the reference or reality. Based on the understanding of the informant on the sign / symbol (efficiency and effectiveness), reflecting the success of the government in implementing the budget, a text / new sign for researchers. Reality perceived by informants over accountancy sign (performance efficiency and performance 
effectiveness) assessed by looking at the relationship between the sign / symbol with referential object.

Based on the philosophy of Baudrillard, the four phases of the relation between the sign (sign) with the referential objects (Baudrillard, 1983, p. 11), Macintosh et al. (2000) describes the relationship between text / mark (sign) with the referential objects into: (1) sign-to-referent as objective reality, (2) sign-to-referent as image, (3) sign-to-referent as a model and (4) sign-to-referent as simulacrum. While Piliang (2012, p. 46) explains the concept of Baudrillard simulation of the complexity of the relation between the sign (sign), image and the reality (reality) as follows: (1) an image is said to be a reflection of reality, when the sign represent reality, (2) image of the mask and the reverse of reality, such as those found at the crime, (3) the absence of masked image of reality, such as those in witchcraft, and (4) the image is not related to any reality, due to the image of a simulacrum of itself (pure simulacrum), the process is referred to as a simulation.

Based on the relation tagging Baudrillard, as well as the interpretation of the meaning informants efficiency performance, the relation between the efficiency performance marks referential reality is classed as a sign-to-referent as image, because the sign does not fully represent reality represented, ambiguous reality (confuse) the concept of efficiency not just based on the fact that, expenditures do not exceed the budget, as well as the realization of outputs in accordance with the plan set out in the budget. Efficiency is only seen on the technical side and economical performance reports based on LPP contained in the budget. Thus some of the realities signified by the performance efficiency is the objective, and others just a concept.

The relation between the effectiveness of the performance mark with referential reality classed as Sign-to-referent as a model, because the sign does not represent the performance of the effectiveness of the objective reality altogether, mark only refers to the simulation model used to assess the performance effectiveness, only mocked reality in mind (mind), The effectiveness of the implementation of the budget performance assessment as understood by most informants, based on the realization of output compared to the output plan specified in the work plan budget, and ignore the result of the budget execution output perceived by the public as the target of the program, which should be represented in the performance effectiveness

\subsection{Hyper Reality Performance Report: Fatamorgana Welfare Justice}

Basing on the vision and mission of the District government XX used as a basis in preparing the planning and budget documents. Performance report must be directed to explain the implementation of the vision and mission of the government to stakeholders. The core of the vision and mission of the District government XX is equitable prosperity or welfare. Through a performance report presented in LPP budget, the government explain the implementation of the budget which is intended to achieve equitable prosperity for the people, through the use of the signs of success are being manufactured by the process of simulating reality specified performance in planning and budget documents. Welfare created indicated by a form of sign / symbol (sign) and image (image). In the case of production of signs and images through a simulated reality in the claim as if as a representation of reality, has been distorted and distorting the public interest to obtain equitable prosperity. Community involvement in the implementation of development planning in regional development planning process, as long as this tends to be done just to fulfill the formal process that is based on the regulation, even impressed a ritual process that seems to community involvement in development planning has really happened. Such conditions would have an impact on government budgeting process that tends to the status quo, not responsive to the wishes or expectations of a dynamic society, in line with the dynamics that occur in the community.

Simulacrum of reality performance showed the successful implementation of the budget through the image (prosperity with justice), although the sign and the resulting image does not depict reality signified prosperity through the performance efficiency and effectiveness of the implementation of programs and activities. Sign / symbol of performance used here to explain something that is not tangible through the game mark, as a mirage of prosperity with justice

Mirage equitable welfare is welfare that had been suppressed by the image that are not related to reality. Through the simulation of reality, a form of welfare mirage showing sign / symbol false, false and even falsehood. Performance effectiveness of the implementation of programs and activities that are based on the achievement of outputs that are identical to the plan presented in the Performance Report, is an example of a sign / symbol of false and superficial that does not reflect the reality of the welfare of society as a target implementation of the budget.

Reality equitable welfare, should also be a concern of government in formulating Performance Report (LPPAPBD). Assessment of the benefits of the implementation of the budget for the improvement of public welfare, is possible if the result or impact (outcomes) of the results (output) the implementation of programs and activities that are perceived by the public as a target implementation of the budget, is also reflected in the performance report. Data is based on the assessment outcome or perception of society as beneficiaries of programs and activities, which are 
juxtaposed with the outcome plan set out in planning documents and budgets.

\section{Conclusion}

Performance efficiency of the implementation of the budget, as long as it is understood by the executive and legislature as efficient use of the budget which is characterized by lower expenditure compared with the budget. While the effectiveness of the performance was marked by the achievement of performance targets or plans as outlined in the report on the performance of each unit in the structure of local government. In a minority of legislators, give attention to the need to pay attention to the interests of the public to assess the performance of the effectiveness of the implementation of programs and activities.

Referring to the relation tagging Baudrillard about the complexity relations between the sign (sign), image (image) and the reality (reality), and based on interpretation of the meaning informants efficiency performance, the relation between the efficiency performance marks referential reality is classed as a sign-to-referent as image, because the sign does not fully represent reality represented. Reality ambiguous (confuse) the concept of efficiency is not simply based on the fact that, expenditures do not exceed the budget, as well as the realization of outputs in accordance with the plan set out in the budget. While the relationship between the effectiveness of the performance mark with referential reality classed as Sign-to-referent as a model, because the sign does not represent the performance of the effectiveness of the objective reality altogether, mark only refers to the simulation model used to assess the performance effectiveness, only mocked reality in mind (mind).

Reality equitable welfare, should be a concern of local governments in compiling the budget LPP. Information about the consequences or impact (outcomes) of the results (output) the implementation of programs and activities that are perceived by the public as a target implementation of the budget, is needed in order to assess the performance of the budget execution in improving the welfare of society. Performance report presented in LPP budget, should be equipped with outcome information, which is based on judgment or perception of society as beneficiaries of programs and activities, and juxtaposed with the outcome plan set out in planning and budget documents.

\section{References}

Anthony, \& Govindarajan. (2004). Management Control System (11th ed.). McGraw Hill.

Atkinson, A., A., Waterhouse, J. H., \& Wells, R. B. (1997). A Stakeholder Approach to Strategic Performance Measurement Sloan. Management reviews, 25-37.

Baudrillard, J. (1983). Simulation. New York: Semiotext.

Belkaoui, A. R. (1980). The inter professional Linguistic Communication of Accounting Concepts: An Experiment in sociolinguistic. Journal of Accounting Reserch, 18(2), 362-374.

Cavalluzzo, K. S., \& Ittner, C. D. (2004). Implementing Performance Measurement Innovations: Evidence from the Government. Accounting Organizations ang Society, 29, 243-267.

Christensen, \& Laegreid. (2001). New Public Management: The effects of contractualism and Devolution on political control. Public Management Review, 3, 73-94.

Creswell, J. W. (2009). Qualitative, Quantitative, and Mixed Methods Approaches (3rd ed.). Sage Publications. Thousand Oaks California.

Denton, D. K. (2005). Professional Practice: Measuring Relevant Thing. International Journal of Productivity and Performance Management, 54(4), 278-287.

Halachmi, A. (2005). Performance Measurement is Only One Way of Managing Performance. International Journal of Productivity and Performance Management, 54(7), 502-516.

Harb, A. (2003). Hermeneutics Truth. LKIS. Yogyakarta.

Hidayat, M. A. (2012). Suing Modernism: Recognize Range Postmodernism Thought Jean Baudrillard. Mold 1.Jalasutra. Yogyakarta.

Hopper, K., \& Pratt, M. (1995). Discourse and Retoric: The Case of the New Zealand Native Land Company. Accounting, Auditing and Accountability Journal, 8(1), 10-37.

Hoque, Z. (2005). Securing legitimacy institutional or organizational effectiveness? A case examining the impact of public sector reform initiatives in an Australian local authority.International Journal of Public Sector Management, 18(4), 367-382.

Hoque, Z. (2006). The methodological Issues in Accounting Research. London: Spiramus. 
Hoque, Z., \& Moll, J. (2001). Public Sector Reform: Implications for accounting, accountability and performance of stated-owned entities-an Australian perspective. International Journal of Public Sector Management, 14(4), 304-326.

Ijiri, Y. (1975). Theory of Accounting Measurement.Accounting Research Study, 10. Sarasota: American Accounting Association.

Kaelan. (2002). Philosophy of Language: Language Reality, Logic Language, Hermeneutics and Postmodernism. Third mold.Paradigm. Yogyakarta.

Macintosh, N. B., Shearer, T., Thornton, D. B., \& Welker, M. (2000). Accounting as simulacrum and hyperreality: Perspectives on income and capital. Accounting Organizations and Society, 25, 13-50.

Mattessich, R. (2003). Accounting representation and the rings are a model of reality: A comparison with Baudrillard's orders of simulacra and his hyper reality. Accounting Organizations and Society, 28, 443-470.

Mwita, J. I. (2000). Model Performance Management: A Systems-Based Approach to Public Service Quality. International Journal of Public Sector Management, 13(1), 19-37.

Nugroho. (2010). Meaning and Reference VIP Thought According to GottlobFrege. Journal of Philosophy Driyarkara, 2, 3-16.

Piliang, Y. A. (2003). Hipersemiotika: Interpretation of Cultural Studies Upon Death of Meaning. Jalasutra. Yogyakarta.

Piliang, Y. A. (2010). Post-Reality: Reality Culture in the Era of Post-Metaphysics. Jalasutra. Yogyakarta.

Piliang, Y. A. (2012). Semiotics and Hipersemiotika: code, style and meaning death. Sun. Bandung.

Republic of Indonesia. (2003). Law of the Republic of Indonesia No. 17 Year 2003 on State Finance.

Republic of Indonesia. (2004). Law of the Republic of Indonesia No. 1 Year 2004 on State Treasury.

Republic of Indonesia. (2004). Law of the Republic of Indonesia No. 15 Year 2004 on the Management and State Financial Responsibility.

Republic of Indonesia. (2004). Law of the Republic of Indonesia No. 32 Year 2004 on Regional Government.

Republic of Indonesia. (2004). Law of the Republic of Indonesia No. 33 Year 2004 on Financial Balance between the Central Government and Local Government.

Republic of Indonesia. (2006). The Indonesian Government Regulation No. 82006 on Financial Reporting and Performance Government Agencies

Republic of Indonesia. (2007). Government Regulation No. 3 of 2007 on Regional Government report to the Government, Accountability Description Report To the Regional Head Regional Representatives Council, and Regional Government Information Reports to the People.

Republic of Indonesia. (2008). The Indonesian Government Regulation No. 8 Year 2008 on stages, the procedures for making, control and evaluation of the Regional Development Plan.

Republic of Indonesia. (2010). Regulation of the Minister of the Interior No. 54 Year 2010 on the implementation of PP No. 8 Year 2008 on stages, the procedures for making, control and evaluation of the Regional Development Plan.

Republic of Indonesia. (2010). The Indonesian Government Regulation No. 71 Year 2010 About the Government Accounting Standards.

Riduwan, A. (2012). Reality In The mirror cracked: Profit Accounting Interpretations in Frame Business Practitioner Non-Accountants. Equity: Journal of Economics and Finance, 16(2), 125-163.

Riduwan, A. I., Triyuwono, G. I., \& Ludigdo, U. S. (2010). Profit Accounting: Study of Critical-postmodernists Derridean. Journal of Accounting and Finance of Indonesia, 7(1), 38-60.

Robinson, P. (2003). The Government Accountability and Performance Measurement. Critical Perspectives on Accounting, 14, 171-186.

Sugiyono. (2012). Understanding Qualitative Research. Seventh mold. Alfabeta. Bandung.

Suwardjono. (2005). Theory of Accounting: Financial Reporting engineering. Yogyakarta: BPFE. 


\section{Copyrights}

Copyright for this article is retained by the author(s), with first publication rights granted to the journal.

This is an open-access article distributed under the terms and conditions of the Creative Commons Attribution license (http://creativecommons.org/licenses/by/3.0/). 